\title{
Review of Ecological Floating Bed Restoration in Polluted Water
}

\author{
Yu Deng, Fuquan Ni* \\ College of Information and Engineering, Sichuan Agricultural University, Ya'an, China \\ Email: ${ }^{*}$ nfq1965@163.com
}

Received September 16, 2013; revised October 18, 2013; accepted November 17, 2013

Copyright (C) 2013 Yu Deng, Fuquan Ni. This is an open access article distributed under the Creative Commons Attribution License, which permits unrestricted use, distribution, and reproduction in any medium, provided the original work is properly cited.

\begin{abstract}
Using Ecological Floating Bed (EFB) to purify polluted water is a process of ecological restoration at virgin position, as well as a complicated physical, chemical and biological process. Its core is utilizing aquatic plants and root's microbes to absorb nitrogen and phosphorus elements, degrade organic matter and enrich heavy metal. EFB has been applied to some water pollution control projects at home and abroad, and has got several achievements. However, there are some factors influenced the removal rate of pollutants, including plants, temperature, seasons, processing time, coverage and initial concentration of pollutants. In the future, the development orientation has been prospected from plant and its combinations, the transformation of EFB structure and the utilization of aquatic resources, and probed the technology of EFB's building and management, to implement the win-win of landscape benefit and ecological function.
\end{abstract}

Keywords: Ecological Floating Bed; Polluted Water; Aquatic Plants; Purification

\section{Introduction}

The issue of water pollution is becoming serious in China. According to China's State of the Environment Bulletin (2012) [1], the water quality monitoring sections of rivers, Grade V and worse than Grade V were $20.9 \%$ and $10.2 \%$ respectively; the water quality's section of lakes, Grade IV - V and worse than Grade V were $27.4 \%$ and $11.3 \%$ respectively and their main pollutants were $\mathrm{NH}_{4}-\mathrm{N}, \mathrm{TP}$ and $\mathrm{COD}_{\mathrm{Mn}}$. Polluted water restoration is a difficult engineering, not only for physical and chemical restoration methods' huge investments, difficult operations, secondary pollution, but also for those methods' poor governance effect which is mainly caused by the complexity of pollutant source and the great difficulty of removing nutrients. Hence, EFB technology which mainly depends on plants should be used to restore polluted water, not only because of its small investments, high efficiency, no secondary pollution and other advantages, but also because that it can bring higher benefit in ecological environment and landscape so that it becomes major concern. EFB was also called Ecological Floating Island and Artificial Floating Island, which utilized the technical principle of soilless culture with the carriers such as bamboo and high macromolecular materials, adopted the technology of

\footnotetext{
*Corresponding author.
}

planting plants on the surface without soil integrated by modern agronomy and ecological engineering method [2], was a kind of water's ecological restoration at virgin position. Using that technology not only cut down the materials such as nitrogen and phosphorus in water to purify water, but also gained economic benefit as the same as land cultivation does or even higher one [3], and constructed water landscape to obtain ecological benefit. In recent years, both home and abroad, it's concerned that the research on EFB technology's removal rate, engineering application and aspect factors. In the future, the development orientation will be prospected from plant and its combinations, the transformation of EFB structure as well as the utilization of aquatic resources, and probed the technology of EFB's building and management.

\section{Research on EFB Mechanism in Polluted Water Restoration}

EFB in polluted water restoration is a complicated physical, chemical and biological process. It is generally acknowledged that using EFB technology to restore polluted water is to utilize aquatic plants' developed roots to contact water, forming a concentrated natural filtering layer, as well as absorbing, adsorption, transforming and degrading the water pollutants. Plants' roots can also se- 
crete large amount of enzyme and organic acid to accelerate the decomposition of the macromolecular pollutants in water and improve the bioavailability of nitrogen and phosphorus. Meanwhile, plants' roots provide microorganism with oxygen source and attachment place and enhance their metabolism to cut down water pollutants' content. Through shifting the plants out and separating them from water, the purpose of purifying water quality is achieved.

\subsection{Absorption of Nitrogen and Phosphorus}

Aquatic plants have an obvious effect on removing nitrogen and phosphorus elements in eutrophic water [4,5]. Aquatic plants make the rapid accumulation of biomass come true in the way of vegetative reproduction. As indispensable nutrient elements in plants' growing process, the inorganic nitrogen and phosphorus in water could be absorbed directly by plants through their roots' absorption, and then plant protein or organic component were synthesized to facilitate plants' growth and development. Therefore, plants had a strong capacity of fixing nitrogen and phosphorus [6]. When aquatic plants were shifted out of water, the nitrogen and phosphorus absorbed by them were brought out of water too, thus the purpose of purifying water was achieved. In the research on EFB's purification in intensive aquaculture pond, water spinach floating bed's highest direct absorption rates of TN and TP on the 100 days were 52.35 and $5.39 \mathrm{~kg} \cdot \mathrm{hm}^{-2} \cdot \mathrm{a}^{-1}$ [7]. Canna was a very good kind of sewage treatment plants, and its highest removal rates of nitrogen and phosphorus were 130 and $23 \mathrm{~kg} \cdot \mathrm{hm}^{-2} \cdot \mathrm{a}^{-1}$ [8]. If the EFB was made up of canna and other plants, its removal rates of nitrogen and phosphorus would be much better, and they reached 314.6 and $156 \mathrm{~kg} \cdot \mathrm{hm}^{-2} \cdot \mathrm{a}^{-1}$ [9]. Cress has a strong capacity of purifying eutrophic water, its removal rates of TN and TP reached $76.86 \%$ and $90.45 \%$ at 20 days treatment [3]. There was a positive correlation between EFB's removal rates of nitrogen and phosphorus in water and plants' growth speed, concentration of nitrogen and phosphorus in water $[10,11]$.

In the research on the water purification mechanism of aquatic plants, it is found that except that the plants themselves absorb nitrogen and phosphorus in water, roots' microbes' activity is an important way of removing nitrogen and phosphorus in water, mainly because microbes' activity can accelerate the decomposition of nitrogen and phosphorus around roots, enhance other elements' activity, and improve the bio-availability of nitrogen and phosphorus [12]. Therefore, the exertion of EFB technology's purification function not only depends on plants' absorption of nitrogen and phosphorus, but a bigger factor is that EFB constructs a micro ecosystem which is in favor of microbes' inhabitation so that nitrogen and phosphorus can be removed effectively.

\subsection{Degradation of Organisms}

EFB not only can remove nitrogen and phosphorus elements effectively, but it also is effective in removing organics $[13,14]$. Canna and calamus floating bed's removal rates of $\mathrm{COD}_{\mathrm{Mn}}$ were $42.3 \%$ and $36.3 \%$ respectively [14]. However, the main ways of removing organic matters by EFB were the degradation of roots secretion as well as absorption and utilization of microbes. Aquatic plants constantly secreted a great deal of macromolecular organics to the environment in the process of growth, such as enzyme, saccharide, organic acid, etc. [15]. Those secretions not only decomposed organic matters effectively, but it also provided roots' microbes with many nutrient substances. Moreover, the oxygen produced by floating plants' photosynthesis was released to water through plants' roots [16], then many anoxic and aerobic areas were formed around its rhizosphere to intensify both aerobic microbes' and anaerobic microbes' growth and reproduction, to promote microbes' constant absorption and utilization of organic pollutants in water, and to raise its degradation efficiency of organic matters, thus achieving the propose of removing organic matters. For example, samphire's removal of humic like proteinoid, DOC and other organic matters were implemented by its rhizosphere's activity [17].

\subsection{Enrichment of Heavy Metals}

Aquatic plants are usually planted in EFB's upper layer, and many aquatic plants are capable of absorbing, metabolizing, enriching heavy metals, besides, the content of heavy metals within the plants themselves was related to the outside world's pollution level, so EFB was regarded as an important way of controlling heavy metal pollution in water, hydrilla varticillata and myriophyllum spicatum were together exposed in the different concentration of $\mathrm{Cu}^{2+}$ of water after two weeks [18], their absorption behaviors coincide with Langmuir model [19] and a strong enrichment capacity is manifested. Water hyacinth was a kind of plants that accumulates $\mathrm{Ni}, \mathrm{Pb}, \mathrm{Zn}$, $\mathrm{Cd}$, and $\mathrm{Cu}$ effectively, because in the wild environment water hyacinth's roots' accumulations of $\mathrm{Cu}, \mathrm{Ni}$ and $\mathrm{Zn}$ are 2 to 17 times that of part above ground and their maximum Bioconcentration factor (BCF) are 1344.6, 1250.0 and 22758.6 respectively [20]. The enrichments of $\mathrm{Pb}$ and $\mathrm{Cd}$ for lotus within roots' every organ were positively correlated with their concentrations and an effective enrichment was demonstrated under combined stress of $\mathrm{Pb}$ and $\mathrm{Cd}$. Among all the organs, lotus leaves and swollen stems enriched the most, but the enrichment of $\mathrm{Pb}$ and $\mathrm{Cd}$ within lotus roots may cause certain toxic reactions [21]. Typha latifolia has a strong capacity of absorbing and enriching $\mathrm{Pb}, \mathrm{Zn}, \mathrm{Cd}$ and $\mathrm{Cu}$, and they were mainly enriched at the root of plant [22]. Jiang and Wang 
[23] showed that after 21 days for reed to deal with 2 $\mathrm{mmol} \cdot \mathrm{L}^{-1} \mathrm{Zn}^{2+}$ of sewage and after the reed is dried, its roots', stems' and leaves' enrichments of $\mathrm{Zn}^{2+}$ are 14.34, 0.95 and $1.45 \mathrm{mg} \cdot \mathrm{g}^{-1}$ respectively. If canna is used to deal with copper-containing wastewater, its removal rate of $2 \mathrm{mg} / \mathrm{L}$ of copper-containing wastewater can reach $74 \%$, and its roots', stems' and leaves' maximum absorption quantities of copper are 1859.04, 186.20 and 127.53 $\mathrm{mg} \cdot \mathrm{kg}^{-1}$ respectively [24].

\section{EFB Technique Application}

At the beginning of the $20^{\text {th }}$ century, EFB technique started and it was used for birds' habitat and fish's spawning place. In the 1980s, German scholars designed the modern EFB and used it to purify polluted water for the first time [25]. Because EFB not only can restore polluted water, but it also avoids several issues, such as huge investments caused by physical and chemical methods, difficult operations and secondary pollution, EFB was promoted and applied rapidly in Japan, Europe and America and other developed countries. China brought in EFB technology in the 1990s, which is now applied to governing polluted urban rivers, lakes as well as reservoirs and it has had a favorable effect on purification and ecological landscape.

Guangzhou city used EFB as a major ecological restoration measure to govern the Yufeng Chung, the south Pai Chung and Guan Chung around the Asian Games Town, as a result that water transparency was improved, water eutrophication was controlled effectively and a favorable effect of landscape and ecology was made [26, 27].

In the water quality improvement project of Bailian Jing River's EXPO garden section, Shanghai, a EFB made up of sliver carp and bighead carp, hyriopsis cumingii and plants was constructed in section. Nine months after operation, the section's comprehensive water quality was transformed from Grade V and worse than Grade V to Grade II-III. It was found that the water quality of all the floating bed sections of calamus, blood grass and Acorus gramineus cv. Variegates reached the Grade III standard, so that the river channels' water quality was improved effectively.

In the water purification project of Dianshan Lake's water source, a research was conducted for one year in the water area with area of 18,000 square meters by utilizing EFB technology. It's shown that EFB purified eutrophic water effectively, because DO content of pilot site was increased 2.06 and $0.38 \mathrm{mg} \cdot \mathrm{L}^{-1}$ respectively compared to that of Qiandun Riverside's inflow and that of pilot site's inflow, besides, its transparency was increased $8.1 \mathrm{~cm}$ and $7.4 \mathrm{~cm}$ respectively. The floating bed experimental project's maximum removal amount of $\mathrm{TN}$, TP and COD in Qiandun Riverside's inflow was 14.9,
0.90 and $58.3 \mathrm{~g} \cdot \mathrm{m}^{-2} \cdot \mathrm{d}^{-1}$; its maximum removal amount in floating bed site's inflow was 5.27, 0.36 and 25.13 $\mathrm{g} \cdot \mathrm{m}^{-2} \cdot \mathrm{d}^{-1}[28,29]$.

EFB technology also has an effect on controlling urban rivers. The research on the experiment of Xinjiao Riverside River and Huifeng River's black and smelly section showed that EFB obviously removed $\mathrm{COD}, \mathrm{NH}_{4}^{+}-\mathrm{N}$, TN and TP; after controlling, the outflow's concentration and transparency were increased; river's biodiversity was significantly boosted; water eutrophication was obviously improved [30].

\section{The Factors of EFB's Purifying Effect}

\subsection{Plant}

There is a great discrepancy of purifying effect on water pollutants owing to different EFB plants species' different physiological properties [31], therefore, selecting proper EFB plants is one of the key factors that affects water purification. Research showed that yellow flag floating bed's removal rates of TN and TP are canna's 2.82 and 5.31 times, besides, yellow flag was proposed as the major plants of urban water EFB because of its freeze resistant capacity was much stronger [32]. There was an obvious discrepancy among canna's, thalia dealbata's and willow herb's removal rates of TN and TP, and both canna's and dealbata's removal rates of TN and TP were higher than that of willow herb [33]. Research on applying four plant floating bed species such as canna, cyperus altrnlifolius, pontederia cordata and calamus to improve the eutropic water in tributary area of The Three Gorges Reservoir showed that canna's maximum removal rate of TP was higher than that of cyperus altrnlifolius, pontederia cordata and calamus [34]. It was generally considered that the purifying effect of the floating bed plants with developed roots was better than that of the floating bed plants with undeveloped roots; the purifying effect of the floating bed plants with high growth rate was better than that of the floating bed plants with low growth rate [35]. That's mainly because plants with developed roots and with high growth rate could obtain more component, thus plant's purifying effect of water pollutants was facilitated.

\subsection{Temperature}

Temperature is a requirement for floating bed plants' growth and reproduction. When the temperature is high, floating bed plants' growth metabolism is vigorous and its purifying effect of water pollutants is obviously improved. For example, when the water temperature was risen from $2^{\circ} \mathrm{C}$ to $29^{\circ} \mathrm{C}$, canna's removal rates of TN and TP were distinctly increased. When the temperature was higher than $10^{\circ} \mathrm{C}$, canna removed $\mathrm{TP}$ and $\mathrm{TN}$ in water obviously; when the temperature was lower than $10^{\circ} \mathrm{C}$, 
canna's growth was at a standstill [36,37]. Research showed that cress floating bed's and water cress floating bed's removal rates of TN and TP in eutropic water of $22^{\circ} \mathrm{C}$ were clearly higher than that of $10^{\circ} \mathrm{C}$ and $35^{\circ} \mathrm{C}$ [38]; eichhornia crassipes floating bed's removal rates of TN and TP in eutropic water of $25^{\circ} \mathrm{C}$ are higher than that of $15^{\circ} \mathrm{C}$ and $35^{\circ} \mathrm{C}$. Those explained that plant's removal rates of $\mathrm{TN}$ and $\mathrm{TP}$ were not proportional to temperature, but they were related to floating bed plants' biomass [39]. All above said that plants' growth rate was different under different temperatures, and at the optimum temperature, plants grown vigorously and its purifying effect of polluted water was obvious, and when the temperature was much too high or low, plants' growth was restrained, thereby, its purifying effect of polluted water was influenced.

Seasonal variation also affects plants' purifying effect. EFB's removal rates of TN and TP in summer and autumn were significantly higher than in winter and spring, and its major reason was that floating bed plants' removal capacity was related to its own growth condition and metabolism [40]. Summer and autumn are temperaturebias floating bed plants' vigorous periods of growth, hence, the plants demonstrate a high purifying rate [41]. However, there're researches indicating that canna floating bed's removal effect of nitrogen in spring was better than in autumn [42], because spring and summer were canna's growth periods, and it primarily stops growing and began to fall off after the middle of July [37].

\subsection{Processing Time}

Floating bed plants' purifying effect of sewage is closely related to processing time. For example, yellow flag, canna and siberian iris floating bed's purifying effects of nitrogen and phosphorus in polluted water increased with the growth of time [32]. Lycopus, wood betony, rumex japonicas and garden sorrel floating bed's purifying effects of nitrogen and phosphorus in sewage increased with the growth of time, moreover, in the first 30 days plants' removal effects were obvious, while 30 days later its removal velocity declined [5]. With the growth of processing time (such as 24 hours, 48 hours, 72 hours and 96 hours), watermifoil's and water caltrop's enrichments of $\mathrm{Cd}^{2+}$ increased with the growth of processing time too [43]. Studies have found that with the growth of processing time, the removal rate of water pollutants had the tendency to firstly increase and then decrease. Ajayi and Ogunbayo used water hyacinth to purify sewage and found that the content of BOD, $\mathrm{Fe}$ and $\mathrm{Cu}$ in water firstly increases and two weeks later gradually decreases [44].

\subsection{Coverage}

Floating bed plants' purifying efficiency of water pollut- ants is directly related to floating bed's coverage: if the coverage increases, the purifying efficiency will be improved correspondingly. For example, compared to $10 \%$ coverage's and 15\% coverage's water spinach floating beds, $20 \%$ coverage's water spinach floating bed's purifying effects of nitrogen and phosphorus were more obvious, and its economic value was higher [7,45]. Cyperus alternifolius floating bed's removal rates of nitrogen and phosphorus in eutrophic water also had the tendency to increase with the growth of coverage $(39 \%>26 \%>13 \%)$ [46]. Under different coverage of water hyacinths' purifying effects of TN and TP in water, the removal rates of TN and TP raised with the increase of water hyacinth's coverage, in addition, when its coverage was more than $80 \%$ in flowing water, the removal rates were higher; while when its coverage was less than $50 \%$, the purifying effects were better [4].

\subsection{Initial Concentration}

Initial concentration of water pollutants is one of the important factors affecting floating bed's purifying effect too. Within the threshold that may cause death, the greater water pollutants' concentration was, the stronger floating bed plants' absorbing ability of pollutants was [47]. The research on using water hyacinth to purify the water which contained $0,40,80,100,150$ and $200 \mathrm{mg} \cdot \mathrm{L}^{-1} \mathrm{ni}-$ trogen showed that with the increase of nitrogen's concentration, water hyacinth's removal amount of nitrogen increased, and the corresponding removal amount was $0.47,5.69,9.31,11.86,16.97,22.13 \mathrm{mg} \cdot \mathrm{L}^{-1}$ [48]. The research on water hyacinth's enrichments of $0-4 \mathrm{mg} \cdot \mathrm{L}^{-1}$ $\mathrm{Cd}$ and $\mathrm{Zn}$ in water showed that with the increase of concentration of $\mathrm{Cd}$ and $\mathrm{Zn}$ in water, their content enriched by roots and buds increased too [49].

\section{Prospects}

\subsection{Plants Selection}

Floating bed plants selection is one of important aspects in EFB research. When choose floating bed plants in polluted water restoration, usually except choosing the aquatic plants with large biomass, strong adaptability, good stain resistance and high removal rate of pollutants as floating bed plants, and some factors' influence should be comprehensively taken into consideration, such as regional characters, freeze resistance capacity and seasons. Most aquatic plants have a poor freeze resistance capacity, so the plants' capacity of removing pollutants obviously decreases in low-temperature winter. In future research, the selection of aquatic plants which are suitable to grow in low-temperature environment and have a strong capacity of removing multiple pollutants should be strengthened. Using plant tissue cultured to select plants not only lower the cost and it was not limited by seasons, but 
it also strengthened plants' restoration capacity, so it was a research hotspot in the future [50].

Applying the floating bed combined by various plants to purifying polluted water environment is a research direction in the future too. At present, most reports have been concentrated on the research on a single plant's purifying effect of polluted water, but it is difficult for a single plant to overcome the influence of various factors that affect purifying effect, so its capacity of purifying is limited. However, utilizing compound EFB constructed by multiple aquatic plants not only can overcome the obvious disadvantage that a single plant's unstable purifying effect is caused by seasonal changes [33,51], but also can exert the advantage of various aquatic plants' growth difference in time and space, and achieve EFB's continuous and stable operation through optimal configuration. Nonetheless, the wonder that which plants' combination can obtain the best purifying effect requires strengthened research.

\subsection{Improvement of EFB}

Traditional EFB which is mainly made up of floating bed frame body, floating bed body, floating bed matrix and floating bed plants cuts down nitrogen, phosphorus, heavy metals, organic matters and so on through planting aquatic plants, but its effect of water purification is undesirable. Improvement of EFB structure is one of the ways to promote floating bed's purifying effect. At present, transformation of EFB structure has been mainly made up of one or more of these things, such as floating bed system and contact oxidation system, aerating system, aquatic plants, microbes, paddings and biological purification tanks, which takes full advantage of floating bed's cubical space, lengthens food chains in floating bed system and strengthens floating bed's enrichment specialty of microbes, thus improving purifying effect. For example, some researches have exploited a new frame-type floating bed made up of "plants, paddings and microbes" by using the principle of "biological symbiosis mechanism", and its purifying effect is obviously better than traditional floating bed [52]. Li have built a combined a cubical floating bed ecological system whose main body was made up of aquatic plants, aquatic animals and microbes, and in which removal rate of pollutants was raised [53]. Transformation of EFB structure makes plants, paddings and microbes function together as the primary things in pollutants removal instead of only plants, but how each part is organically combined can improve purifying effect more effectively remains to be further studied in the future.

\subsection{Resource Utilization of Aquatic Plants}

Aquatic plants grow rapidly and have large biomass, so a great number of aquatic plants need to be gained during the period of floating bed's operation. Nitrogen and phosphorus absorbed by plants can be transformed into proteins and other nutrient materials which are good resources and have certain economic value. If aquatic plants can't be dealt with timely and effectively, they will decay in water, as a result that this not only causes secondary pollution but wastes valuable resources. At present, ways of utilizing aquatic plants have mainly been phytoextraction, exploitation of medical resources, forage production [6] and edible vegetables [3]. However, utilization of aquatic plants is still an important limiting factor of their ecological restoration in water environment, and how to improve utilization rate of aquatic plants will be a future research direction.

\subsection{Engineering Application}

EFB has already been a common purification technology in eutrophic water. There are many engineering cases at home and abroad having gotten good purifying effect, but there are many problems too. For instance, because floating bed plants' purifying capacity has certain volatility, different environments (such as seasons, wind speeds, wave heights and so on) may affect the purifying effect; when floating bed's purifying capacity has reached saturation or when apoptosis seasons come, shift of plants will cost much time and use great efforts; EFB plants' daily managements (such as pest control, plants management in winter and so on) fail to form systematic specification; EFB's service life is short, generally less than 6 years [54]; there have been no technologies and management standards to reference in engineering application by far. Although EFB technology has outstanding merits, above problems are hindering EFB technology's application and promotion. Therefore, how to apply it to practical engineering more effectively needs further systematical research.

\section{Acknowledgements}

The study was supported by the International Scientific and Technological Cooperation Project (2012DFG91520), and Innovative Research of Sichuan Provincial Department of Science and Technology (2012ZZ045).

\section{REFERENCES}

[1] Environment Protection Ministry of People's Republic of China, "China's State of the Environment Bulletin," 2012.

[2] Z. Y. Ren and C. G. Deng, "Application of Ecological Floating Bed Technology," Journal of Agro-Environment Science, Vol. 26, 2007, pp. 261-263.

[3] M. H. Hu, J. Yuan and X. E. Yang, "Eutrophication Purification and Resource Utilization by Aquatic Vegetables," 
Journal of Lake Sciences, Vol. 22, No. 3, 2010, pp. 416420.

[4] J. Q. Wang, Y. F. Zhi, Y. Z. Song, et al., "Purification Effect of Water Hyacinth (Eichhornia crassipes) Coverage on the Different Flow Properties Water Bodies," Ecology and Environmental Sciences, Vol. 21, No. 1, 2012, pp. 124-129.

[5] G. F. Xu, "Study on Purified Efficiency of Phosphorus and Nitrogen from Eutrophicated Landscape Water by Four Floating Ornamental Plants," Chinese Agricultural Science Bulletin, Vol. 26, No. 7, 2010, pp. 299-302.

[6] H. W. Xu and Y. Lu, "Research Advances of Aquatic Plants in Water Ecological Restoration," Chinese Agricultural Science Bulletin, Vol. 27, No. 3, 2011, pp. 413-416.

[7] J. Z. Chen, S. L. Meng, H. D. Hu, et al., "Effect of Ipomoea Aquatica Cultivation on Artificial Floating Rafts on Water Quality of Intensive Aquaculture Ponds," Ecology and Environment in the Countryside, Vol. 26, No. 2, 2010, pp. 155-159.

[8] L. Li, Y. Yang, F. J. Yang, et al., "Growth Characteristic Features and Behaviors of Aquatic Plants in the Polluted Water," Journal of Safety and Environment, Vol. 11, No. 3, 2011, pp. 14-19.

[9] Y. Z. Zhen, G. Li, J. Du, et al., "Effect of Biological Floating Island on Water Quality and Algae in a Tributary Bay Typical of the Three-Gorge Reservoir," Journal of Ecology and Rural Environment, Vol. 29, No. 3, 2013, pp. 278-283.

[10] M. W. Jayaweera, J. C. Kasturiarachchi, R. K. A. Kularatnea, et al., "Contribution of Water Hyacinth (Eichhornia crassipes (Mart.) Solms) Grown under Different Nutrient Conditions to Fe-removal Mechanisms in Constructed Wetlands," Journal of Environmental Management, Vol. 87, No. 3, 2008, pp. 450-460. http://dx.doi.org/10.1016/j.jenvman.2007.01.013

[11] L. J. Fox, P. C. Struik, B. L. Appleton, et al., "Nitrogen Phytoremediation by Water Hyacinth (Eichhornia crassipes (Mart.) Solms)," Water Air Soil Pollut, Vol. 194, 2008, pp. 199-207. http://dx.doi.org/10.1007/s11270-008-9708-X

[12] K. H. Lu, R. Y. Hu, J. J. Liang, et al., "Characteristics of Rhizosphere Microbial Community Structure of Two Aquatic Plants in Eutrophic Waters," China Environmental Science, Vol. 30, No. 11, 2010, pp. 1508-1515.

[13] S. T. Luo, Y. J. Zhang and J. Y. Li, "Effect of Combination of Submerged Macrophyte With Ecological Floating Bed on Aquacultural Pollution Controlling," Journal of Ecology and Rural Environment, Vol. 27, No. 2, 2011, pp. 87-94.

[14] F. P. Bu, G. Y. Luo, X. Y. Xu, et al., "Canna indica and Acorus Calamus Ecological Floating Beds for Purification of Micro-Polluted Source Water," China Water \& Wastewater, Vol. 26, No. 3, 2010, pp. 14-17.

[15] W. Liu, J. R. Qiu, Z. B. Wei, et al., "Effects of Different Plants and Plant Root Exudates on Wastewater Purification," Journal of Environmental Engineering, Vol. 3, No. 6, 2009, pp. 971-976.

[16] X. P. Cheng, Z. B. Wu and Y. Z. Xia, "Review on Gas Exchange and Transportation in Macrophytes," Acta Hy- drobiological Sinica, Vol. 27, No. 4, 2003, pp. 413-417.

[17] L. F. Huang, J. F. Zhuo Jianfu, W. D. Guo, et al., "Tracing Organic Matter Removal in Polluted Coastal Waters via Floatingbed Phytoremediation," Marine Pollution Bulletin, Vol. 71, 2013, pp. 74-82. http://dx.doi.org/10.1016/j.marpolbul.2013.03.032

[18] C. Z. Yan, A. Y. Zeng, X. C. Jin, et al., "Equilibrium Sorption Isotherm for $\mathrm{Cu} 2+$ onto Hydrilla verticillata Royle and Myriophyllum spicatum," Environmental Science, Vol. 27, No. 6, 2006, pp. 1068-1072.

[19] T. A. Davis, B. Volesky and A. Mucci, "A Review of the Biochemistry of Heavy Metal Biosorption by Brown Algae," Water Research, Vol. 37, 2003, pp. 4311-4330. http://dx.doi.org/10.1016/S0043-1354(03)00293-8

[20] D. M. Hammad, "Cu, Ni and $\mathrm{Zn}$ Phytoremediation and Translocation by Water Hyacinth Plant at Different Aquatic Environments," Australian Journal of Basic and Applied Sciences, Vol. 5, No. 11, 2011, pp. 11-22.

[21] C. H. Xiong, X. G. Xu, Y. E. Lu, et al., "Canna Indica and Acorus calamus Ecological Floating Beds for Purification of Micro-Polluted Source Water," Acta Horticulturae Sinica, Vol. 39, No. 12, 2012, pp. 2385-2394.

[22] C. S. Yang, C. Y. Lan and W. S. Shu, "Accumulation and Distribution of Heavy Metals in Artificial Wetland with Typhalatifolia," Water Treatment Technology, Vol. 28, No. 2, 2002, pp. 101-104.

[23] X. Jiang and C. Wang, "Zinc Distribution and Zinc-Binding Forms in Phragmites Australis under Zinc Pollution," Journal of Plant Physiology, Vol. 165, 2008, pp. 697704. http://dx.doi.org/10.1016/i.jplph.2007.05.011

[24] J. Yu, C. X. Huang, Q. Liang, et al., "Disposal of Coppercontaminated Water with Canna indica Ecological Floating Bed," Anhui Agricultural Sciences, Vol. 40, No. 12, 2012, pp. 7331-7333.

[25] K. Nakamura and Y. Shimatani, "Water Purification and Environmental Enhancement by the Floating Wetland," Proceeding of 6th IAWQ Asia-Pacific Regional Conference in Korea, 1997.

[26] M. M. He, C. Zhu and Z. J. He, "Application and Landscape Effects of Eco-Floating Bed in the Guangzhou Asian Games City's River," Guangzhou Garden, Vol. 6, 2010, pp. 10-13.

[27] Y. Y. Huang, M. Jiang, Y. J. Zhang, et al., "Building Artificial Floating-Island for Treating Bailianjing River in Shanghai," Environmental Science and Technology, Vol. 33, No. 8, 2010, pp. 108-133.

[28] C. J. Sun, Y. J. Gao, Y. Cao, et al., "Study on Design and Effect of Estuary Ecological Floating Bed Pilot Project at Dianshan Lake," China Water \& Wastewater, Vol. 26, No. 18, 2010, pp. 64-68.

[29] Y. J. Gao, R. L. Ruan, C. J. Sun, et al., "Research on Purification Effect of Ecological Floating Bed Experimental Project in Qiandunpu Estuary Region in Dianshan Lake," Water Resources Protection, Vol. 27, No. 6, 2011, pp. 28-31.

[30] Y. H. Chen, Y. Zhang, M. S. Huang, et al., "Demonstration Work on Purification of Urban Polluted Rivers by Staged Floating Treatment Wetlands," Journal of East 
China Normal University (Natural Science Edition), Vol. 1, 2011, pp. 111-118.

[31] X. R. Mao and J. B. Zhou, "Research on Water Quality Purification Capacity of Several Species of Aquatic Plants Commonly Used by Ecological Floating Bed," Journal of Zhejiang Agricultural Sciences, Vol. 1, 2011, pp. 157159.

[32] L. M. Wu, H. B. Cong, X. F. Wang, et al., "Effect of Three Kinds of Floating-bed Plants and Artificial Plants on Nitrogen and Phosphorus Removal in Water," Environmental Technology, Vol. 23, No. 3, 2010, pp. 12-16.

[33] Y. Jiang, Y. Tong, W. H. You, et al., "Research on Comparison of the Growth Characteristics and the Optimize Configuration Modes of the Nitrogen and Phosphorus Uptake Capacity of Three Kinds of Plant Cultivated on the Floating-Bed," China Environmental Science, Vol. 31, No. 5, 2011, pp. 774-780.

[34] V. K. Mishra, A. R. Upadhyay, S. K. Pandey and B. D. Tripathi, "Concentrations of Heavy Metals and Aquatic Macrophytes of Govind Ballabh Pant Sagar an Anthropogenic Lake Affected by Coal Mining Effluent," Environmental Monitoring and Assessment, Vol. 141, 2008, pp. 49-58. http://dx.doi.org/10.1007/s10661-007-9877-x

[35] Y. Ge, J. Chang, X. Y. Wang, et al., "Relationship between the Physiological Characters and Purification Ability of Different Plants in Waters with Two Trophic Levels," Acta Ecological Sinica, Vol. 20, No. 6, 2000, pp. 1050-1055.

[36] J. F. Zhen, G. Y. Luo, X. Y. Xu, et al., "Purification of Heavily Polluted River Water by Ecological Floating Bed at Low Temperatures," China Water \& Wastewater, Vol. 24, No. 21, 2008, pp. 17-20.

[37] G. Y. Luo, F. P. Bu, X. Y. Xu, et al., "Effect of Temperature on the Ecological Floating bed System," China Environmental Science, Vol. 30, No. 4, 2010, pp. 499-503.

[38] M. H. Hu, J. H. Yuan, X. E. Yang, et al., "Effects of Temperature on Purification of Eutrophic Water by Floating Eco-Island System," Acta Ecologica Sinica, Vol. 30, 2010, pp. 310-318.

http://dx.doi.org/10.1016/j.chnaes.2010.06.009

[39] F. M. Liu, "Effect of Temperature on Eichhornia Crassipes Floating Island Purification," Environmental Protection Science, Vol. 39, No. 3, 2013, pp. 9-11.

[40] F. L. Zhao, S. Xi, X. E. Yang, et al., "Purifying Eutrophic River Waters with Integrated Floating Island Systems," Ecological Engineering, Vol. 40, 2012, pp. 53-60. http://dx.doi.org/10.1016/j.ecoleng.2011.12.012

[41] Y. M. Zhang, Y. X. Gao, X. M. Wu, et al., "Effect of the Technique of Complex Three-Dimensional Ecological Floating-Bed in Removing N and P From Slightly Polluted Water Body," Journal of Ecology and Rural Environment, Vol. 26, No. S1, 2010, pp. 24-19.

[42] L. P. Sun, Y. Liu, C. Feng, et al., "Removal of Nitrogen from Water Bodies by Canna Floating Bed in Different Seasons," Journal of Sun Yat-sen University (Natural Science Edition), Vol. 47, No. 2, 2008, pp. 127-130.

[43] A. Sivaci, E. Elmas, F. Gümüs, et al., "Removal of Cad- mium by Myriophyllum Heterophyllum Michx and Potamogeton crispus L. and Its Effect on Pigments and Total Phenolic Compounds," Archives of Environmental Contamination and Toxicology, Vol. 54, 2008, pp. 612-618. http://dx.doi.org/10.1007/s00244-007-9070-9

[44] T. O. Ajayi and A. O. Ogunbayo, "Achieving Environmental Sustainability in Wastewater Treatment by Phytoremediation with Water Hyacinth (Eichhornia Crassipes)," Journal of Sustainable Development, Vol. 5, No. 7, 2012, pp. 80-90.

[45] S. Chao, J. Z. Chen, X. P. Ge, et al., "The Control of Nitrogen and Phosphorus to Tilapia Fish Pond by FloatingBed-Grown Water Spinach (Ipomoea aquatica)," Chinese Agricultural Science Bulletin, Vol. 27, No. 23, 2011, pp. 70-75.

[46] Y. Q. Liu, G. Y. Zou, X. F. Song, et al., "Response of Phytoplankton Community to a New Ecological Floating Bed System (EFBS) in Enclosures with Eutrophicated Water,' Research of Environmental Science, Vol. 24, No. 11, 2011, pp. 1233-1239.

[47] Q. Wang and S. P. Cheng, "Review on Phytoremediation of Heavy Metal Polluted Water by Macrophytes," Environmental Science and Technology, Vol. 33, No. 5, 2010, pp. 96-102.

[48] L. J. Fox, P. C. Struik, B. L. Appleton, et al., "Nitrogen Phytoremediation by Water Hyacinth (Eichhornia Crassipes (Mart.) Solms)," Water Air Soil Pollution, Vol. 194, 2008, pp. 199-207. http://dx.doi.org/10.1007/s11270-008-9708-x

[49] X. M. Lu, K. Maleeya, P. Prayad, et al., "Removal of Cadmium and Zinc by Water Hyacinth, Eichhornia crassipes," Science Asia, Vol. 30, 2004, pp. 93-103. http://dx.doi.org/10.2306/scienceasia1513-1874.2004.30. $\underline{093}$

[50] C. F. Zhou, S. Q. An, J. H. Jiang, et al., "An in Vitro Propagation Protocol of Two Submerged Macrophytes for Lake Revegetation in East China," Aquatic Botany, Vol. 85, 2006, pp. 44-52.

http://dx.doi.org/10.1016/j.aquabot.2006.01.013

[51] X. H. Chen, C. J. Sun, Y. Cao and Y. J. Gao, "Research on Effects and Factors of Applying Ecological Floating Bed Technology to Governing Eutrophic Shallow Lakes," Proceedings of the 2010 Academic Annual Meeting of Chinese Society for Environmental Sciences (Volume III), 2010, pp. 2595-2600.

[52] J. Q. Fan, G. Y. Zou, X. F. Song, et al., "Effects of FCEFB and TFB on the Nitrogen Removal and Nitrogen Cycling Microbial Community in a Eutrophic River," Research of Environmental Science, Vol. 24, No. 8, 2011, pp. 850856.

[53] W. Li, X. N. Li, D. W. Cao, et al., "Effect of Combined Ecological Floating Bed Technology on Improvement of Eutrophic Source Water Quality," China Water \& Wastewater, Vol. 24, No. 3, 2008, pp. 34-38.

[54] B. Guo and W. Zhang, "Application of Ecological Floating Bed in Dianshan Lake's Eutrophic Water Restoration," China Science and Technology Information, Vol. 23, 2010, pp. 16-17. 